\title{
Interconnected business models: present debates and future agenda
}

\author{
Milan focevski \\ Department of Industrial Economics and Management, KTH Royal Institute of Technology, Stockholm, Sweden and \\ Department of Management Engineering, Polytechnic University of Milan, Milan, Italy \\ Niklas Arvidsson \\ Department of Industrial Economics and Management, KTH Royal Institute of Technology, Stockholm, Sweden, and \\ Antonio Ghezzi \\ Department of Management Engineering, Polytechnic University of Milan, Milan, Italy
}

\begin{abstract}
Purpose - The purpose of this study is to provide a review of the emergent literature to advance the current understanding of the business model (BM) concept in a context in which more than one actor is actively involved in the development and delivery of a joint offer based on information and communication technologies.

Design/methodology/approach - The paper uses a systematic literature review approach. The review is based on 25 systematically selected publications published from 2000 to 2018 and retrieved from bibliographic databases and through a process of snowballing.

Findings - The authors found several alternative conceptualizations of a BM at a network level, which highlighted different elements as core components. Based on this, authors' findings suggest the literature has a fragmented view of what the BM concept entails at a network level, and of which actors are relevant. Conversely, there is a consensus that a single-firm view is inadequate for describing and studying joint value architectures because of its inability to consider all involved actors and their activities and resources. Therefore, a network-oriented view, as a relational aggregator, is seen as a possible way forward.

Originality/value - The study contributes to the current understanding of a BM concept at a network level and suggests three viewpoints from which to interpret value architectures at different levels of analysis: single-firm view, dyadic-level view and network-oriented view. Furthermore, the authors highlight several gaps to be studied and provide avenues for future research opportunities for scholars.
\end{abstract}

Keywords Services, Business model, Ecosystem, Business relationships, Value dimensions, Value network

Paper type Literature review

\section{Introduction}

To stay competitive and survive in the market, companies resort to the innovation of their value propositions, and a common strategy is to base new services on digital technologies (Bygstad and Lanestedt, 2009; Porter and Heppelmann, 2014). In this endeavor, new entrants to the service industry and businesses that move from selling products to providing services and solutions are dependent on information and communication technologies (ICT) and digitalization of information processes (Bouwman et al., 2008; Kindström and Kowalkowski, 2014). Furthermore, the development of such services usually happens at the intersection of various activities executed by different actors with limited competences (Laya et al., 2016; Palo and Tähtinen, 2011). In such complex and dynamic environments, which embody a network rather than a chain structure of value creation, collaboration among key partners from the very start is crucial to ensure that the service

The current issue and full text archive of this journal is available on Emerald Insight at: https://www.emerald.com/insight/0885-8624.htm

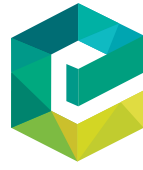

Journal of Business \& Industrial Marketing 35/6 (2020) 1051-1067

Emerald Publishing Limited [ISSN 0885-8624] [DOI 10.1108/JBIM-06-2019-0292] is successfully developed (Basole, 2009; de Reuver et al., 2018). However, the organization of these networked enterprises raises many questions in regard to the traditional views on companies and their business models (BMs), as the lines between enterprises and markets are increasingly blurred (Nenonen and Storbacka, 2010) and the challenges of the networked world

\footnotetext{
(C) Milan Jocevski, Niklas Arvidsson and Antonio Ghezzi. Published by Emerald Publishing Limited. This article is published under the Creative Commons Attribution (CC BY 4.0) licence. Anyone may reproduce, distribute, translate and create derivative works of this article (for both commercial and non-commercial purposes), subject to full attribution to the original publication and authors. The full terms of this licence may be seen at http://creativecommons.org/licences/by/4.0/legalcode

The authors are grateful to the journal editor Professor Wesley Johnston as well as the two anonymous reviewers for their expert and constructive guidance during the review process. The authors thank Angelo Cavallo for his insightful suggestions in bringing this paper to fruition. The paper is produced as part of the EMJD Programme European Doctorate in Industrial Management (EDIM) funded by the European Commission for Education, Audiovisual and Culture Executive Agency, Erasmus Mundus Action 1. In addition, Milan Jocevski acknowledges the generous personal grant from the Swedish Retail and Wholesale Council, as well as the KTH Library for the financial support to publish this work as open access.
}

Received 14 June 2019

Revised 8 September 2019

15 November 2019

Accepted 16 November 2019 
(one of the diverse and fluid connections) are only partially understood through firm-level perspectives (Kleindorfer and Wind, 2009).

The BM concept, which has received significant attention from several authors describing its usefulness for redesigning traditional forms of doing business and new value creation designs enabled by ICT (Amit and Zott, 2001; Timmers, 1998), has developed into several different branches of scholarly literature over the years (Massa et al., 2017). Most authors consider the BM to be the architecture of different value dimensions, among which value creation, delivery and capture are the most common (Foss and Saebi, 2017; Teece, 2010). In the extant literature, authors typically refer to these dimensions as pertaining to a specific firm and argue that BM provides answers on how the business of a single-firm is organized (Casadesus-Masanell and Ricart, 2010; Spieth et al., 2014). Some authors have addressed BM as firm-centric, yet boundary-spanning (Velu, 2016; Zott et al., 2011), and have thus acknowledged the network of actors through the firm's perspective (Chesbrough, 2006; Zott and Amit, 2009, Visnjic et al., 2018). However, an increasing number of authors argue that the development of services based on ICT, which requires an active interaction of different partners, may benefit from the design of a $\mathrm{BM}$ beyond the perspective of a single firm (Leminen et al., 2018; Stott et al., 2016; Westerlund et al., 2014; Wu and Zhang, 2009). The rationale behind such thinking is that the design of BMs at a network level, unlike at a firm level, may shed light on the orchestration of various involved actors, their resources and the necessary activities aimed at developing such services.

Indeed, authors have suggested a shift to an ecosystem perspective that could lead to a richer understanding of the value creation and appropriation regarding digital innovations (Nambisan, 2018) because such processes no longer lie within a single firm but rather include other stakeholders as well (Doganova and Eyquem-Renault, 2009; Hynes and Elwell, 2016; Klimanov and Tretyak, 2019; Nenonen and Storbacka, 2010). In addition, value delivery should be seen as a collaborative effort where the BM indicates the orchestration of actors and activities related to the creation and delivery of value (Oliveira et al., 2018; Storbacka et al., 2013). Other empirical studies and reviews show that this topic is also highly relevant from a practical point of view because a firm's BM innovation and (re-)design in regard to the other actors within the network context have been connected to the firm's performance and competitive advantage (Frankenberger et al., 2013; Klimanov and Tretyak, 2019; Voelpel et al., 2004). However, scholarly studies remain scarce regarding the use and conceptualization of the BM at a network level, so we see a need to further understand a $\mathrm{BM}$ perspective that involves all the firms that participate in the service creation and provisioning of a socalled network-oriented model (Wirtz et al., 2016).

In response to the highly theoretical and practical relevance of the topic, we have conducted a systematic literature review. Hence, this study aims to review the state-of-the-art research on a network and ecosystem view of a BM to advance the current understanding of the BM concept in a context where more than one actor is actively involved and participates in the development and delivery of a service based on ICT. Therefore, the research questions of the study are as follows:
RQ1. How do researchers refer to the concept of a $\mathrm{BM}$ at a network level?

RQ2. What are the particularities of the network-oriented view of a BM?

The contribution of this paper is twofold. First, we highlight various descriptions of the BM concept at a network level and reflect on the current understanding and use of the concept by different scholars. Even though we can observe that these descriptions are different, we see in the reviewed body of literature a consensus among researchers when it comes to the need for and importance of the network-oriented view of a BM. Second, we have highlighted different scholars' efforts and their calls to adjust the BM value architecture to a situation where a joint service development is proposed. These efforts are observed at the network level, which we have identified as one of the three levels of analysis to which the BM can be scaled. The main idea here is that the concept of a BM may be seen from three different viewpoints, which would then allow managers to adopt different levels for BM analysis, namely, a single-firm view, a dyadic-level view or a network-oriented view.

The remainder of this paper is organized as follows: Section 2 briefly discusses fundamental elements and literature on which we base our network-oriented view of BMs, which is followed by Section 3 on methodology. Section 4 outlines different terms used by authors when referring to the concept of a BM in a network context, and Section 5 discusses the current state of knowledge in the field. Finally, in Section 6, the conclusion brings the paper to a close with relevant remarks and suggestions for future research, as well as managerial implications.

\section{Interconnectedness at a network level}

Recent discussions on how companies work and go about their business in a networked digital world have leveraged several existing streams of thought that address the interactions between businesses and their environments. The three prevailing literature streams that served as antecedents to discussions on interconnected BMs are business ecosystem, business network and value network literature. Each, on its own merits, contributes to a growing systemic perspective on how a $\mathrm{BM}$ is conceptualized at a network level and is briefly described here to provide a background to the interconnectedness among businesses at a network level.

The ecosystemic approach described by Nelson and Winter (1982) is the parallel that is drawn between a biological ecosystem and a business ecosystem that has continued to appear in the literature to this day. In their view, and as subsequently suggested in another established line of reasoning on business ecosystems as networks of interconnected organizations (Moore, 1996, 2006), firms are affected by other firms' activities and market changes, just as organisms are in biological systems. Similarly, organizations also co-evolve, in the same way that interdependent species evolve in an endless reciprocal cycle (Moore, 1996). In a digital world, a business ecosystem does not respect traditional industry boundaries; instead, companies from different industries unite to create new 
solutions and experiences, usually around a "keystone" firm (Iansiti and Levien, 2004).

However, there are other streams of thought on organizational interactions, such as network theories. The view of Håkansson and Snehota (1995), where business networks are seen as sets of relationships among business actors, is a possible alternative way to look at the firm's interconnectedness at a network level. In their view, enterprises engage with their relationships to bring complex offers to customers, and each enterprise has a role that depends on the interaction in which it participates. According to Håkansson and Snehota (1993), business relationships that form a business network have two dimensions that evolve over time: elements of relationship exchange (activities, resources and actors) and functions that a relationship can take (on a single actor or at a dyadic or network level). One way to look at this is to view activities performed and resources shared by different actors from different functional perspectives: the perspective of a single actor, a dyad or a network. Important characteristics to mention are that:

- not all actors in the network work toward the same goal, only those that are part of the same activity pattern; and

- every business relationship exists on the precondition that there is a value exchange between the involved actors (Håkansson and Snehota, 2006).

Building on this, we come to the third perspective of how organizations are thought to be interconnected and interacting. The value network perspective is rooted in the path from value chain to value constellation as described by Normann and Ramírez (1993), suggesting that it is not always possible to define fixed positions for firms based on a set of activities along a value chain (Porter, 1985). Instead, they refer to a new logic of value, the value constellations or value networks (Stabell and Fjeldstad, 1998) as a model for observing the overall system, with a focus on the value creation. They see the value creation system as a pattern of interactivity that connects actors as different co-creators of value (Ramirez and Mannervik, 2016). In a similar vein, Christensen (1997, p. 32) saw a value network as "a context within which a firm identifies and responds to customers' needs, solves problems, [...] reacts to competitors, and strives for profit." $\mathrm{He}$ also suggested that value networks are formed around technological trajectories and that different value networks can be part of one industry.

Although the discussion has predominantly been on interfirm relationships because they are often dependent on numerous complementary resources for the provision of complex products and services (Basole, 2009), the consumer as the user and potential co-creator of the service should not be forgotten. For example, Alee (2003) argued that value networks are a purposeful group of people and organizations that are creating social and economic good through complex dynamic exchanges. She also offered a way to map those patterns of exchange, envisioning it as a perspective through which to examine both internal and external-facing network value-creating activities (Alee, 2009). Therefore, thinking of value as the benefit provided to consumers of the service and actors creating it, we look at the value and the process of its creation and delivery as a way to understand the relationships between different actors and the general orchestration of actors, resources and activities. In addition, whether talking about business ecosystems, business networks or value networks, it is clear that a network-oriented view is needed to understand the interconnectedness of different actors and the consequences it has on the conceptualization of BMs at a network level.

Indeed, several scholars have highlighted the need to understand the concept of a BM that relies on network level value creation processes (Bankvall et al., 2017), where the main idea is that such BMs can provide a wider conceptualization of networked value creation. Other authors have had similar thoughts when it comes to an overarching view of the BM in the context of interdependent ventures, and have referred to it as an ecosystem BM (Leminen et al., 2015). Moreover, Saebi and Foss (2015) argued for organizational flexibility, and that open BMs must allow organizational permeability and co-creation of value with other actors and users, which are considered as "key resources"; and Zott and Amit (2008) point out the need to understand how a BM can influence the positioning of the firm in its business environment.

Finally, based on the assumption that the relationship between two firms is built on a relationship between the firms' BMs (Ghezzi, 2013), it is in the BM that the company relates to its external environment (Osterwalder and Pigneur, 2010) and with other actors' BMs in an activity system (Zott and Amit, 2010). It is in such systems that Iansiti and Levien (2004, p. 68) have argued that "stand-alone strategies do not work when a company's success depends on the collective health of the organizations that influence the creation and delivery of their product"; and it is in such a networked world that we argue for a better understanding of a BM concept. Therefore, we will rely on the three presented perspectives (i.e. business ecosystem, business network and value network) to inform the discussion on the BM concept at a network level. We summarize these perspectives with specific focal points in Figure 1, and assume that despite being developed in separate silos, the reasoning behind each of them relies on the same idea of interconnectedness at a network level. In addition, such an idea is in line with the previously argued need for a network-oriented view of a BM.

\section{Method}

In this study, we used a systematic literature review approach a method to analyze and synthesize the findings of a number of systemically selected publications in a transparent and replicable manner (Tranfield et al., 2003). Such systematic literature reviews often follow a detailed procedure composed of several well-defined steps (see, e.g. Karakaya and Nuur, 2018; Klang et al., 2014; Miterev et al., 2017). Therefore, in the

Figure 1 Framework used to inform the discussion on the BM concept at a network level

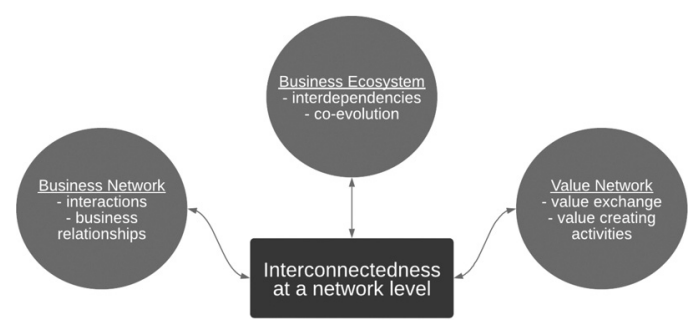


planning stage of our study, we first identified the research problem and question, which later helped us to design the sampling procedure and criteria for the inclusion of publications for our review. Later on, during the execution of the review, we relied on the research aim and the question to guide our literature analysis and synthesis. We did this in a critical manner, highlighting current references to the $\mathrm{BM}$ in a network context and discussing major gaps identified during the analysis process, finishing with suggestions for further research based on our analysis of where the topic might be heading (Hart, 1998). The study adopts a multi-step process that includes a sampling procedure, data analysis and data synthesis, as depicted in Figure 2.

\subsection{Step 1}

Typically, articles in academic peer-reviewed journals are regarded as validated knowledge with significant impact on the field, and are therefore often used as the sole sources for literature reviews (Podsakoff et al., 2005). However, in this study, we include the diverse body of literature that was not subject to the traditional peer-review process, such as book chapters, because such practice has been noted to bring positive contributions to systematic reviews in management and organizational studies (Adams et al., 2017). We searched for relevant articles in the Web of Science and SciVerse Scopus databases as two of the most comprehensive and commonly used databases. Because the latter is less selective than the

Figure 2 Flowchart of the used procedure

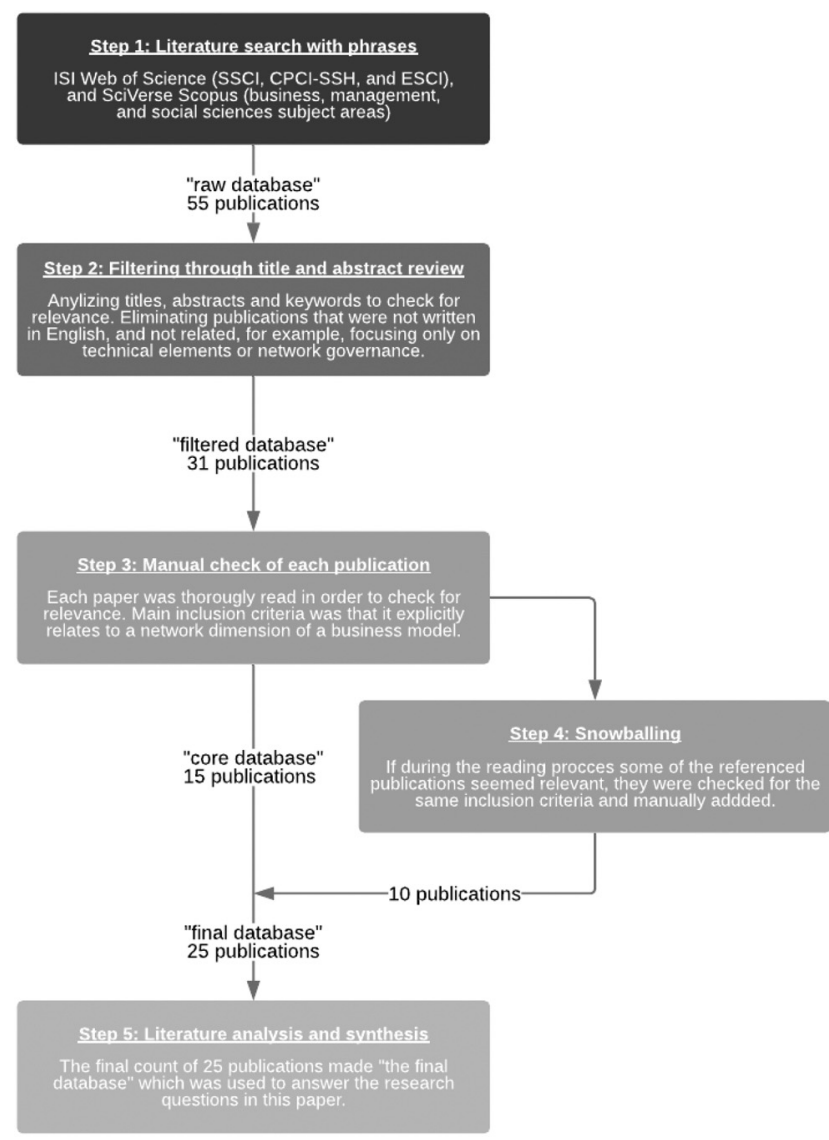

former (Cavallo et al., 2018; Ghezzi et al., 2018), it provides a source of publications that are more receptive to emerging topics in the literature. At the same time, it is not as broad as, for example, Google Scholar, which includes a much broader range of various "gray" publications (Adams et al., 2017).

According to Laya et al. (2018), the concepts of "networked," "network-centric," "network-embedded," and "ecosystem" BMs reflect the same network-oriented view of BMs. Searching for each of these keywords in combination with "business model"” (by using Boolean operator "AND") would yield a significantly high number of hits, creating the basis for a broad discussion. We aimed for a more in-depth discussion on how researchers refer to the concept of a BM at a network level and the particularities of the network-oriented view of a BM. Therefore, to search the databases, we created four sets of search phrases using wildcard characters to cover a broader range of potential hits. We used "network* business model" and "ecosystem* business model" ${ }^{*}$ " to search for publications where those word combinations would appear together. In addition, such searches would yield results such as "network business model" or "networked business models." However, because the hyphen is treated as punctuation and therefore ignored in such searches, we included two more phrases to cover additional potential hits, namely, "network-centric business model"” and "network-embedded business model"”.

These four phrases were searched for in the title, abstract and keywords of each publication indexed in the SSCI, CPCI-SSH and ESCI of Web of Science. The same phrases were also used in a search carried out in the Scopus database, where an additional filter on the subject area was implemented. We opted to limit the search to publications in the business, management and social sciences fields because the terms "network" and "ecosystem" have been used in different areas, such as telecommunications and computing. As has been previously noted the Scopus database is less selective, so the number of publications that we obtained from this database was higher in comparison to the Web of Science. We had no limitation on the date range, and the search was performed on 19 August 2019. In total, excluding publications that appeared in both databases and incomplete entries, this step resulted in 55 publications (i.e. the "raw database").

\subsection{Step 2}

Abstracts, along with retrieved documents' titles and keywords, were initially read to check and refine whether all 55 publications were relevant to the study. When it was not possible to assess whether the publication fitted the scope based only on the title, keyword and abstract, the full text of the publication was scanned and analyzed to make the final decision. This step resulted in the exclusion of 24 publications, and thus the inclusion of 31 for the next step (i.e. the "filtered database").

\subsection{Step 3}

Afterwards, each of the 31 publications was subject to full reading to determine whether it was relevant for the study. Each publication was checked to see whether it satisfied our three research criteria and should be considered for inclusion in the "final database." The three criteria were: 
1 the document had to derive, state or rely on a previously published BM definition;

2 the publication discusses in a nontrivial manner a network dimension of a BM; and

3 if an article had an empirical research approach, it should have been done in a setting that relies on ICT.

Such criteria were guided by our research questions and intention to focus on a context where more than one actor is actively involved and participates in the development and delivery of a service based on ICT. In doing so, we do acknowledge the general discussion concerning the concept of a $\mathrm{BM}$ at a network level, but when it comes to the empirical domain, we delimit the review to publications where the value proposition is based on ICT.

\subsection{Step 4}

To increase the comprehensiveness of this review and minimize biases against relevant articles not found in our search, we extended the sampling with the snowballing process (Santos and D'Antone, 2014). Such a procedure is believed to be particularly useful for complementing database searches and extending systematic literature studies (Wohlin, 2014). Therefore, during the reading of publications in Step 3, we paid special attention to notice any cited publication that was relevant but did not appear during our search (Step 1). For example, a work could have been published in a peer-reviewed journal that is open source, but not indexed in either of the searched databases. When such a publication was noticed, it was read thoroughly and checked to see whether it satisfied our three research criteria stated in Step 3. The same applied to any publication in the "filtered database." If they did meet the criteria, we would include them in our "core database." In total, ten additional publications met the criteria and were therefore included during the process of snowballing in our "final database".

\subsection{Step 5}

In sum, this procedure led us to the identification of 25 articles (i.e. the "final database") that met all our criteria and thus were thoroughly reviewed to answer our research questions. They are listed in Table I. We classified each publication along the following three dimensions inspired by Klang et al. (2014):

1 formal conceptualization of the BM concept in a networked context;

2 methodological approach and empirical phenomenon under study; and

3 the reference to the discussed literature on interconnectedness (see chapter two), i.e. business ecosystem, business network or value network literature stream.

When it came to classifying contributions according to the used definitions/conceptualizations of the BM concept in a network context, we distinguished between publications that had explicit definitions and those that used definitions offered by somebody else (Massa et al., 2017). In cases where authors used the concept without defining it, we categorized that publication within the latter group. Tables II and III contain further details. Moreover, based on the methodological approach and research design, conceptual publications and literature reviews (as well as one introduction to a special issue) were classified as "conceptual," whereas empirical papers that could have included some theory development, and empirical literature reviews, were classified as "empirical" (Table I). Finally, under the identified themes within each of the papers from the "final database," we have addressed the core principles referring to the characteristics of the theoretical foundation literature used (see chapter two).

We primarily used tables as exploratory devices that would help us to compare and contrast publications from the "final database" within each of the three dimensions. After identifying different themes in articles, which are presented in the last column in Tables II and III, we performed qualitative clustering (Miles and Huberman, 1994) which yielded directions for further discussion (i.e. synthesis). This step also helped us highlight underdeveloped topics and define future research directions, and served as the final stage of the literature review.

\subsection{A first look at the literature}

The historical distribution of publications shows an increasing interest in the topic during the last two decades, with the number having grown at a substantially higher rate during the last five years (Figure 3). Although the majority of the sample is published in peer-reviewed journals, more than 30 per cent of publications were presented at conferences or published as book chapters (Figure 4). These facts speak to the novelty of the topic. The papers selected came mainly from the marketing management field, where some were published in outlets that are more technically oriented but have used a business perspective in an empirical context.

\section{Defining a network-oriented view of a business model}

Before digging deeper into the analysis of the literature, it is worth reflecting on the meaning that is given to the concept of a $\mathrm{BM}$ in a network context. Two streams are identified in the "final database." In the first, authors coin new terms or use terms already used by other authors to highlight the difference of a BM concept in a network context from previous firmcentric BM conceptualizations (Table II). The second stream in our "final database" is composed of a minority of authors who assume that one of the fundamental traits of a BM concept is that it explains how a firm relates to its environment and the relationships that a firm has with other actors in a network (Table III). Authors in this stream continue to use the term $B M$ without any modifiers, while heavily stressing different network elements as core components in descriptions of a BM. In other words, they seem not to believe that there is a need for a new conceptualization of the BM concept in a network context, in the way that authors in the preceding stream do. Nevertheless, by building on the idea that a BM can be conceptualized, i.e. be formally described (Massa et al., 2017), both of these streams contribute to the notion that the BM concept can and should include elements relating to a business' environment and the inherent interconnectedness of different organizations.

By looking more closely at the used definitions/ conceptualizations, it can be observed that there is no dominantly used term for the BM concept. We have found 
Table I Selected studies with a network-oriented view of business models

\begin{tabular}{|c|c|c|c|}
\hline Reference $^{*}$ & Title & Source & $\begin{array}{l}\text { Research } \\
\text { strategy }\end{array}$ \\
\hline $\begin{array}{l}\text { Andersson et al. } \\
(2014)^{*}\end{array}$ & Service innovations enabled by loT & 30th Annual IMP Conference & Empirical \\
\hline $\begin{array}{l}\text { Bankvall et al. } \\
\text { (2017) }\end{array}$ & Conceptualizing BMs in industrial networks & Industrial Marketing Management & Conceptual \\
\hline $\begin{array}{l}\text { Dellyana et al. } \\
\text { (2018) }\end{array}$ & $\begin{array}{l}\text { Managing the actor's network, BM and BM innovation to } \\
\text { increase value of the multidimensional value networks }\end{array}$ & International Journal of Business \& Society & Empirical \\
\hline Ehret et al. (2013) & $\begin{array}{l}\text { BMs: Impact on business markets and opportunities for } \\
\text { marketing research }\end{array}$ & Industrial Marketing Management & Conceptual \\
\hline $\begin{array}{l}\text { Ghanbari et al. } \\
(2017)^{*}\end{array}$ & Business development in the loT: A matter of vertical cooperation & IEEE Communications Magazine & Empirical \\
\hline $\begin{array}{l}\text { Gordijn et al. } \\
(2000)^{*}\end{array}$ & What's in an electronic BM? & $\begin{array}{l}\text { Knowledge Engineering and Knowledge } \\
\text { Management: Methods, Models, and Tools }\end{array}$ & Empirical \\
\hline $\begin{array}{l}\text { Harmon and } \\
\text { Castro-Leon (2018) }\end{array}$ & $\begin{array}{l}\text { Service innovation in the Cloud: Implications for strategy } \\
\text { development }\end{array}$ & $\begin{array}{l}\text { Technology Management for Interconnected World } \\
\text { Service }\end{array}$ & Empirical \\
\hline $\begin{array}{l}\text { Heikkilä and } \\
\text { Heikkilä }(2010)^{*}\end{array}$ & Conscripting of network BMs & The IUP Journal of Business Strategy & Empirical \\
\hline livari et al. (2016)* & Toward ecosystemic BMs in the context of industrial Internet & Journal of Business Models & Conceptual \\
\hline $\begin{array}{l}\text { Ikävalko et al. } \\
\text { (2018) }\end{array}$ & Value creation in the IoT: Mapping BMs and ecosystem roles & Technology Innovation Management Review & Empirical \\
\hline Jabłoński (2015) & The economization of network BMs & Management of Network Organizations & Conceptual \\
\hline Jekov et al. (2017) & Study on the IoT ecosystem BMs and the segment of startups & $\begin{array}{l}\text { 10th Annual International Conference of Education, } \\
\text { Research and Innovation }\end{array}$ & Empirical \\
\hline $\begin{array}{l}\text { Komulainen et al. } \\
(2006)^{*}\end{array}$ & BM scenarios in mobile advertising & $\begin{array}{l}\text { International Journal of Internet Marketing and } \\
\text { Advertising }\end{array}$ & Empirical \\
\hline Laya et al. (2018) & $\begin{array}{l}\text { Network-centric BMs for health, social care and well-being } \\
\text { solutions in the internet of things }\end{array}$ & Scandinavian Journal of Management & Empirical \\
\hline $\begin{array}{l}\text { Leminen et al. } \\
\text { (2018) }\end{array}$ & $\begin{array}{l}\text { The future of the Internet of Things: toward heterarchical } \\
\text { ecosystems and service BMs }\end{array}$ & Journal of Business and Industrial Marketing & Empirical \\
\hline $\begin{array}{l}\text { Markendahl et al. } \\
\text { (2017) }\end{array}$ & On the role and potential of loT in different industries & $\begin{array}{l}\text { Internet of Things Business Models, Users, and } \\
\text { Networks }\end{array}$ & Empirical \\
\hline $\begin{array}{l}\text { Palo and Tähtinen } \\
\text { (2013) }\end{array}$ & $\begin{array}{l}\text { Networked BM development for emerging technology-based } \\
\text { services }\end{array}$ & Industrial Marketing Management & Empirical \\
\hline $\begin{array}{l}\text { Palo and Tähtinen } \\
\text { (2011) }\end{array}$ & $\begin{array}{l}\text { A network perspective on BMs for emerging technology-based } \\
\text { services }\end{array}$ & Journal of Business \& Industrial Marketing & Empirical \\
\hline $\begin{array}{l}\text { Storbacka et al. } \\
(2012)^{*}\end{array}$ & Designing BMs for value co-creation & $\begin{array}{l}\text { Special Issue - Toward a Better Understanding of the } \\
\text { Role of Value in Markets and Marketing }\end{array}$ & Conceptual \\
\hline $\begin{array}{l}\text { Suherman and } \\
\text { Simatupang (2017) }\end{array}$ & $\begin{array}{l}\text { The network BM of cloud computing for end-to-end supply chain } \\
\text { visibility }\end{array}$ & International Journal of Value Chain Management & Empirical \\
\hline $\begin{array}{l}\text { Turber et al. } \\
(2014)^{*}\end{array}$ & Designing BMs in the era of IoT: towards a reference framework & $\begin{array}{l}\text { Advancing the Impact of Design Science: Moving from } \\
\text { Theory to Practice }\end{array}$ & Empirical \\
\hline $\begin{array}{l}\text { van der Borgh et al. } \\
(2012)\end{array}$ & $\begin{array}{l}\text { Value creation by knowledge-based ecosystems: Evidence from a } \\
\text { field study }\end{array}$ & R\&D Management & Empirical \\
\hline $\begin{array}{l}\text { Westerlund et al. } \\
(2014)^{*}\end{array}$ & Designing BMs for the loT & Technology Innovation Management Review & Conceptual \\
\hline Wirtz et al. (2016)* & BMs: Origin, development and future research perspectives & Long Range Planning & Conceptual \\
\hline $\begin{array}{l}\text { Ziouvelou and } \\
\text { McGroarty (2018) }\end{array}$ & A BM framework for crowd-driven loT ecosystems & $\begin{array}{l}\text { International Journal of Social Ecology and } \\
\text { Sustainable Development }\end{array}$ & Conceptual \\
\hline
\end{tabular}

several instances of the use of ecosystem, ecosystem's or ecosystemic BM, as well as network, networked and sometimes network-centric or network-embedded BM. Moreover, the debate is still open in respect to what a $\mathrm{BM} i s$, what it does, relates to, includes, and so on. Some of the authors in our "final database" offer questions as dimensions to represent the BM (Ikävalko et al., 2018; Turber et al., 2014), which we use as cues to understand how researchers refer to the concept of BM in a network context. Specifically, the four questions we use for that purpose are - who, what, how and why.

The first question is who, and refers to the actors that are part of a BM at a network level, their roles and the value exchange 
Table II List of publications that offered working definitions and conceptualizations of the business model concept in a networked context

\begin{tabular}{ll}
\hline Reference & Used definition/conceptualization \\
\hline $\begin{array}{l}\text { Andersson et al. } \\
\text { (2014) }\end{array}$ & $\begin{array}{l}\text { They refer to networked BM as dynamic devices to develop } \\
\text { "strategic nets" of cooperating actors, with a more or less } \\
\text { defined leadership, serving as mental models and devices to } \\
\text { explore the market, to shape and coordinate action and to aid } \\
\text { the development from pilot stage to full-scale market } \\
\text { introduction }\end{array}$ \\
Bankvall et al. & $\begin{array}{l}\text { A network-embedded BM relies on network level value } \\
\text { (2017) }\end{array}$ \\
& not clearly processes and business exchange patterns that are
\end{tabular}

Ghanbari et al. The network-centric BM framework uses the BM concept to (2017) understand business planning in a value network. The framework contains three elements: business network, opportunity and model development

Harmon and Castro- Enterprises shift to networked BM by developing multisided Leon $(2018)^{* *}$ service platforms. Therefore, value creation shifts from the firm to a market network of users, partners and other actors within a service ecosystem

Heikkilä and Heikkilä (2010) ${ }^{* *}$

livari et al. (2016) ${ }^{* *}$ Network BM has, besides long-lasting customer relationships, four core components: product/service, finance, technology and network structure

Ecosystemic BM for loT is "oblique" where the ecosystem is seen as a whole and the relationships among partners are no longer based on customer-supplier relationships but organizations are now dependent on each other, interact to achieve common strategic objectives and eventually share a common fate

Ikävalko et al. The loT ecosystem BM view answers questions such as: who (2018) are the collaborators, why do they participate, and where are the sources of value creation?

Jabłoński $(2015)^{* *}$

The network BM is the concept of core values offered to customers, and the configuration of the network of delivering value consisting of one's own strategic capabilities and other values in the network (e.g. outsourcing, alliances), and the constant attempts of the company to change and meet stakeholders' objectives

Jekov et al. (2017) An ecosystem BM is a BM composed of value pillars anchored in ecosystems and focuses on both the firm's method of creating and capturing value and any part of the ecosystem's method of creating and capturing value

Komulainen et al. (2006)

Laya et al. (2018)

Leminen et al. (2018)
The core elements of a network BM include the product/ service, the business actors and their roles, and the valuecreating exchanges among the actors

Network-level BM guides how a net of companies will create customer and network value by developing a collective understanding of the business opportunities and shaping the actions to exploit them

Ecosystem BM i.e. value design expands the BM thinking beyond organizational boundaries and demonstrates how value is created and captured in an ecosystem. It can be conceptualized by four pillars: value drivers, value nodes, value exchanges and value extracts

Core themes addressed within the publications

Type of conceptualization*

Used definition offered by Palo Actors' roles and Tähtinen (2013)

Used their own definition

Used definition offered by Palo and Tähtinen (2013)

The concept is used without a direct definition

The concept is used without a direct definition

The concept is used without a direct definition

Used definition offered by Turber et al. (2014)

The concept is used without a direct definition

Used definition offered by Westerlund et al. (2014)

Used their own definition

Used definition offered by Palo and Tähtinen (2013)

Used definition offered by Westerlund et al. (2014)
BM analysis Firm, relationship and network level

Value flow

Business opportunities Positioning within a business network Value co-creation Multisided platforms Value creation shift

Joint network BM design Knowledge exchange

Organizational boundaries Value creation and value appropriation

Actors' roles in a business ecosystem Focus shift to ecosystem BMs Value co-creation Network as a business ecosystem Long-term relationships

Value pillars, value creation and capture

Move from a single-firm to ecosystem BM

Actors' roles, including end-users Value-creating exchanges

Actors' roles and orchestration activity Resource dependency

Organizational boundaries Value design tool 
Table II

\begin{tabular}{|c|c|c|c|}
\hline Reference & Used definition/conceptualization & Type of conceptualization* & $\begin{array}{l}\text { Core themes addressed } \\
\text { within the publications }\end{array}$ \\
\hline $\begin{array}{l}\text { Markendahl et al. } \\
(2017)^{* *}\end{array}$ & $\begin{array}{l}\text { A network model, where BM networks and partners are } \\
\text { included, highlights the importance of capturing multi-actor } \\
\text { aspects of value creation and how the value network can be } \\
\text { composed }\end{array}$ & $\begin{array}{l}\text { The concept is used without a } \\
\text { direct definition }\end{array}$ & $\begin{array}{l}\text { Move from a single-firm to a } \\
\text { networked BM } \\
\text { Value co-creation }\end{array}$ \\
\hline $\begin{array}{l}\text { Palo and Tähtinen } \\
\text { (2013) }\end{array}$ & $\begin{array}{l}\text { A networked BM guides how a net of companies will create } \\
\text { customer and network value by developing a collective } \\
\text { understanding of the business opportunities and shaping the } \\
\text { actions to exploit them }\end{array}$ & Used their own definition & $\begin{array}{l}\text { Firm-level and networked BN } \\
\text { Novel technology-based serv }\end{array}$ \\
\hline $\begin{array}{l}\text { Palo and Tähtinen } \\
\text { (2011) }\end{array}$ & $\begin{array}{l}\text { The concept of a networked BM refers to the strategic net of } \\
\text { actors involved in developing, producing, and marketing the } \\
\text { technology-based service as well as delivering it to the } \\
\text { customers }\end{array}$ & Used their own definition & $\begin{array}{l}\text { Actors' activities and roles } \\
\text { Business network }\end{array}$ \\
\hline $\begin{array}{l}\text { Suherman and } \\
\text { Simatupang (2017) }\end{array}$ & $\begin{array}{l}\text { The network BM is defined as the logic of how multiple actors } \\
\text { in a supply chain collaborate to achieve integration across the } \\
\text { value network }\end{array}$ & Used their own definition & $\begin{array}{l}\text { Mapping value flow } \\
\text { Multi-actor collaboration }\end{array}$ \\
\hline $\begin{array}{l}\text { van der Borgh et al. } \\
(2012)^{* *}\end{array}$ & $\begin{array}{l}\text { The ecosystem's BM is analyzed from a viewpoint of the } \\
\text { entire ecosystem, and includes four design themes: novelty, } \\
\text { complementarity, efficiency and lock-in adapted to the } \\
\text { ecosystem environment }\end{array}$ & $\begin{array}{l}\text { The concept is used without a } \\
\text { direct definition }\end{array}$ & $\begin{array}{l}\text { Co-evolution of firm's and } \\
\text { ecosystem's BMs } \\
\text { Value drivers }\end{array}$ \\
\hline $\begin{array}{l}\text { Westerlund et al. } \\
\text { (2014) }\end{array}$ & $\begin{array}{l}\text { An ecosystem BM is a BM composed of value pillars anchored } \\
\text { in ecosystems and focuses on both the firm's method of } \\
\text { creating and capturing value as well as any part of the } \\
\text { ecosystem's method of creating and capturing value }\end{array}$ & Used their own definition & $\begin{array}{l}\text { BM design tool } \\
\text { Ecosystem nature of loT } \\
\text { Value design }\end{array}$ \\
\hline Wirtz et al. (2016) ${ }^{* *}$ & $\begin{array}{l}\text { The network BM includes the various, mostly external } \\
\text { interactions of a BM. In the network context, the BM } \\
\text { represents a management tool to check and control the value } \\
\text { distribution with joint value creation }\end{array}$ & $\begin{array}{l}\text { The concept is used without a } \\
\text { direct definition }\end{array}$ & $\begin{array}{l}\text { Management tool } \\
\text { Value distribution }\end{array}$ \\
\hline $\begin{array}{l}\text { Ziouvelou and } \\
\text { McGroarty }(2018)^{* *}\end{array}$ & $\begin{array}{l}\text { A crowd-driven ecosystem BM framework integrates all } \\
\text { relevant value network participants and value-related } \\
\text { activities and processes in an open ecosystem-centric context, } \\
\text { addressing both the "inner" and the "outer" ecosystem } \\
\text { components }\end{array}$ & $\begin{array}{l}\text { The concept is used without a } \\
\text { direct definition }\end{array}$ & $\begin{array}{l}\text { Organizational boundaries } \\
\text { Ecosystem thinking }\end{array}$ \\
\hline
\end{tabular}

Notes: *If the authors of the particular publication referred to a definition offered by somebody from the "final database" it was stated in the table.

${ }^{* *}$ Authors of these publications have used their respective conceptualizations but without direct definition. In other words, we would look for the author's cues to understand their conceptualization, but in some cases, authors did refer to others' definitions/conceptualizations

that happens between them (Komulainen et al., 2006). It is about the orchestration of different actors and the multi-actor approach to value creation (Markendahl et al., 2017) and value delivery (Jabłoński, 2015). What is the second question, and refers to the joint offer, i.e. the value proposition that the configured network of actors is coordinately developing and delivering to customers (Palo and Tähtinen, 2011). The how question helps us understand the $\mathrm{BM}$ concept from an activities perspective, where the $\mathrm{BM}$ is seen as an organizational device to shape and coordinate activities to create customer and network value (Andersson et al., 2014; Palo and Tähtinen, 2013). In addition, it can be used as a design tool to see how value is created and captured in a network (Leminen et al., 2018; Westerlund et al., 2014). Thus, the locus of value creation moves outside organizational boundaries to a network level (Storbacka et al., 2012), at which Bankvall et al. (2017) claim that a (network-embedded) BM can help us to understand the activities needed for joint value creation. At the same time, those activities are the ones that influence how the actors relate to each other (Storbacka et al., 2012), create bonds and design value network composition and multi-actor collaboration (Andersson et al., 2014; Suherman and Simatupang, 2017). Finally, to answer the why question, authors remind us that in the digital and networked world, organizations increasingly depend on each other to achieve common strategic objectives (Iivari et al., 2016). Therefore, the model itself can be used as a boundary object for planning (Heikkilä and Heikkilä, 2010); as a general framework to integrate relevant value network participants and value-related activities and processes (Ziouvelou and McGroarty, 2018); as a management tool to check and control the value distribution with a joint value creation (Wirtz et al., 2016) or to understand business planning in value networks (Ghanbari et al., 2017).

In short, a network-oriented view of BMs underlines the idea that there is a different view that can be taken, distinct from the single-firm view. A network-oriented view can be a useful tool in 
Table III List of publications in which a new term was not used to address the BM concept in a network context

\begin{tabular}{|c|c|c|c|}
\hline Reference & Used definition/conceptualization & $\begin{array}{l}\text { Type of } \\
\text { conceptualization* }\end{array}$ & $\begin{array}{l}\text { Core themes addressed } \\
\text { within the publications }\end{array}$ \\
\hline $\begin{array}{l}\text { Dellyana } \\
\text { et al. (2018) }\end{array}$ & $\begin{array}{l}\text { The BM is the representation of how actors in the network exchange value and } \\
\text { arrange the value flow, where one of the elements of the BM in the network } \\
\text { perspective is the value exchange between network actors }\end{array}$ & $\begin{array}{l}\text { Used definition offered by } \\
\text { Komulainen et al. (2006) and } \\
\text { Palo and Tähtinen (2011) }\end{array}$ & $\begin{array}{l}\text { Multidimensional value } \\
\text { network } \\
\text { Network governance }\end{array}$ \\
\hline $\begin{array}{l}\text { Ehret et al. } \\
\text { (2013) }\end{array}$ & $\begin{array}{l}\text { BMs define a business based on its unique value proposition in a network of } \\
\text { collaborating users, organizations and other stakeholders. The starting point } \\
\text { for BM approaches is to identify the potential for the unique contribution of a } \\
\text { firm within a value-creation system and to define its contractual boundaries } \\
\text { and relationships to its environment }\end{array}$ & Used their own definition & $\begin{array}{l}\text { Actors' roles, performance } \\
\text { and orchestration in } \\
\text { networks } \\
\text { Value delivery }\end{array}$ \\
\hline $\begin{array}{l}\text { Gordijn } \\
\text { et al. }(2000)\end{array}$ & $\begin{array}{l}\text { An e-BM ontology centers around the core concept of value, and expresses } \\
\text { how value is created, interpreted and exchanged within a multi-party } \\
\text { stakeholder network }\end{array}$ & Used their own definition & $\begin{array}{l}\text { Co-creation activities } \\
\text { Value exchange }\end{array}$ \\
\hline $\begin{array}{l}\text { Storbacka } \\
\text { et al. (2012) }\end{array}$ & $\begin{array}{l}\text { The BM is a constellation of interrelated design elements, outlining the design } \\
\text { principles, resources and capabilities (i.e. design layers) related to markets, } \\
\text { offerings, operations, and organization (i.e. design dimensions). A BM } \\
\text { manifests itself in the practices that the focal actor engages in and these } \\
\text { practices influence how the focal actor relates to other actors }\end{array}$ & Used their own definition & $\begin{array}{l}\text { Value co-creation and } \\
\text { value flow } \\
\text { Actor's interactions }\end{array}$ \\
\hline $\begin{array}{l}\text { Turber } \\
\text { et al. (2014) }\end{array}$ & $\begin{array}{l}\text { Dimensions in the BM framework in an loT ecosystem include the value } \\
\text { network of collaborating partners (who), sources of value creation (where) and } \\
\text { benefits from collaboration (why) }\end{array}$ & Used their own definition & $\begin{array}{l}\text { An ecosystem that } \\
\text { includes a customer } \\
\text { Service-dominant logic }\end{array}$ \\
\hline
\end{tabular}

Figure 3 Academic articles, proceedings and book chapters from a "final database"

Cumulative number of publications per year

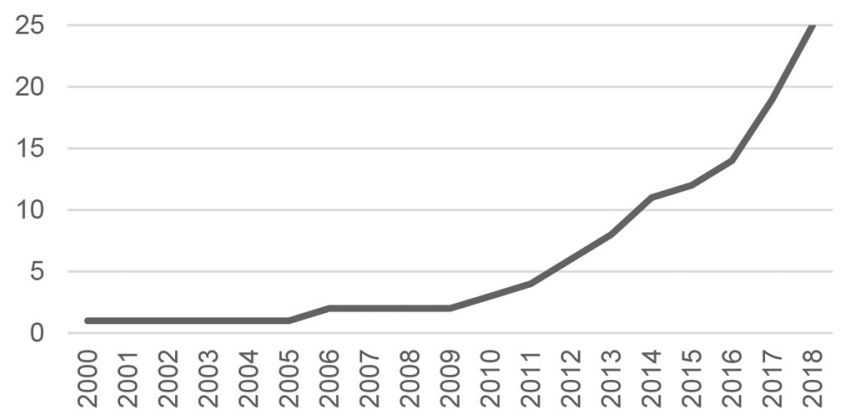

Figure 4 Source of publications

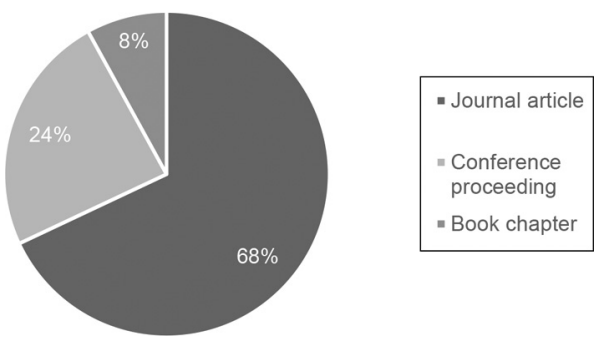

an interconnected environment, without diminishing the importance of a BM used on a single-firm level. Finally, while at the firm level, the concept of a BM refers to the value architecture of one firm, at the network level a BM can be seen as a relational aggregator, orchestrating relationships within the network and guiding the design of a value flow across the network.

\section{The state-of-the-art research on business models at a network level}

We have already highlighted that the particular perspective used by researchers when using a BM concept was focused on the single enterprise (Leminen et al., 2018; Spieth et al., 2014). Although there are examples where a firm's environment is taken into account through the concept of a BM (Zott and Amit, 2009), the used BM view is usually focused on the firm as the focal entity within the environment (Ehret et al., 2013). However, in a networked and digital world, the development of services is not so straightforward if using a single-firm BM perspective (Markendahl et al., 2017). Therefore, alternative views, grounded in different theoretical foundations of firm interconnectedness, have been proposed as a more appropriate $\mathrm{BM}$ perspective for developing joint service offers and understanding business opportunities in networks (Ghanbari et al., 2017; Ikävalko et al., 2018; Jekov et al., 2017).

The development of BMs according to Bankvall et al. (2017) may start either from the firm-level BM and move from there to the dyadic, and then, the network-level BM; or vice versa, may start by designing the network-level BM and then discuss dyad and then each of the BMs of the participating actors individually. Moreover, interaction among actors is the key here because no matter where the design of BMs starts, the interactions dictate both the BM archetypes and the roles of the actors within. Also, because different firms usually participate with firm-centric BMs that could be in mutual conflict (Andersson et al., 2014), it is through interactions that they can be adapted and consolidated. In one of the studies, the companies were working in workshops on a "joint business 
modelling" activity by using a BM as a tool for knowledge exchange (Heikkilä and Heikkilä, 2010). In that study, interactions facilitated by researchers helped business managers realise all the risks related to conflicting incentives and lacking competences, making the process of business modeling fruitful for all. In fact, using a network level BM indirectly improves firms' abilities to achieve high performance (Jabłoński, 2015).

Furthermore, using a network-oriented view, the BM can be seen as a management tool to check and control the value distribution with joint value creation, and can be understood as a link between strategy and the operative management (Wirtz et al., 2016). It has also been used as a planning tool for scenario planning (Komulainen et al., 2006), a dynamic device for planning an emerging business opportunity (Palo and Tähtinen, 2013) and an instrument to see the business from a strategic viewpoint (Suherman and Simatupang, 2017). It is at this higher, network level, which allows the entire system to be understood, unlike at a lower, firm level, where only individual components can be grasped, that Westerlund et al. (2014) argue for a different BM framework; one which they prefer to address as "value design." In such a conceptualization, the discussion revolves around the dynamic nature of the ecosystem BM and the story of "how the engine works" rather than what its components are.

Nevertheless, the argued shift from firm BM to ecosystem BM (Jekov et al., 2017) is noted as a change of management focus (Westerlund et al., 2014) in designing the BM that is based on the input of many actors. It is why the networkoriented view of a BM could shed light on a situation when it is impossible for a single-firm BM to orchestrate the relevant resources and activities needed to develop a joint service (Palo and Tähtinen, 2011), not to mention the coordination of different actors and their roles. In addition, all these elements of network relationships (activities, resources and actors) are a part of each of the BMs, because the BM both shapes the network and is shaped by it (Palo and Tähtinen, 2013).

We see the BM concept as a multi-level device, with which one can take:

- a single-firm view where the BM represents the value architecture of a particular firm;

- a dyadic-level view, where the BM is seen as a linking agent between two actors; and finally

- a network-oriented view, where we see the BM as a relational aggregator.

In such a way, the BM concept allows different viewpoints to be taken to analyze a business solution or a service development at each of the three levels. In other words, it allows for a value architecture to be analyzed from three different viewpoints.

\subsection{Joint value proposition}

With the use of digital technologies, new possibilities for service development arise, and so do new value propositions in those contexts where the involvement of more than one actor is expected. Such service offers lay at the core of the discussion on BMs that are formed and developed around them (Andersson et al., 2014). These services are sometimes created as bundles of existing services, and sometimes follow a path of servitization, i.e. an opportunity to leverage on service-led BMs, instead of focusing on product-centric ones (Iivari et al.,
2016). Furthermore, previously independent actors are increasingly connected through both technical and business ties with the goal of producing smart services. In developing such services, firms adapt their own firm-level BMs and thus extend a firm's scope and scale (Harmon and Castro-Leon, 2018). Interestingly, Palo and Tähtinen (2013) distinguish between service and business opportunity development, where despite being different processes, they run in parallel and determine which of the actors are involved with the service itself, and which with the business in general. For this, the networkoriented view of a BM can be used as a guide.

In some cases, there are reports of multidimensional value networks being formed to create a new business concept and a service based on new technologies (Dellyana et al., 2018). These technologies then become the key for creating new BMs and are resetting the competitive advantage arena (Harmon and Castro-Leon, 2018). In our "final database," there are two dominant examples of such technologies: the Internet of Things (IoT) and cloud computing (Appendix).

Finally, it is also worth mentioning that the trend of transforming firm-centric activities toward network-centric activities was seen as a change to service-dominant logic (Turber et al., 2014). In line with such logic and service cocreation activities, Ikävalko et al. (2018) argue that a networkoriented view of a BM can make sense of the roles of each of the actors for the service development, as well as helping to understand their firm-level BM options.

\subsection{Actors' roles in the network}

In order for the service development and delivery to function properly as a joint value proposition of several different cooperating parties, it is necessary for each and every one of those involved to understand their roles. Moreover, these roles are not fixed over time and may be adapted in line with changing ecosystem conditions, which is why network constellations and individual roles have long been considered part of a BM concept. Therefore, the network-oriented view is essential, so that the relevance of the external environment would be recognized (Turber et al., 2014). In other words, firms (i.e. different actors) are interconnected, and therefore their activities are co-dependent and usually evolve around the activities of one specific focal firm (Ghanbari et al., 2017). Their resources also exhibit dependency that provides a basis for the emergence of new solutions (Laya et al., 2018). Dynamic network governance is attributed to employees of the focal firm, who can reflect on business relationships based on duration, trust and frequency of interaction (Dellyana et al., 2018). Nevertheless, discussions around these activities, shared resources and the roles each firm takes need to be embedded in the development process because the scope of change covers all involved actors (Bankvall et al., 2017) and each has to position itself so as to guarantee the success of the entire ecosystem, not just a single firm (Ghanbari et al., 2017).

In the empirical studies we have analyzed, the dominant context is one of IoT ecosystems (Appendix). Authors thus refer almost exclusively to BMs that pertain to the creation of IoT services as ecosystem BMs because they tie the offered service and value architecture to the ecosystem within which the service is developed. There, in a co-evolving ecosystem, the concept of a BM connects the firm with its environment, 
customers and society as a whole for joint utilization of complementary capabilities (Iivari et al., 2016). It is used so as to enable one to understand value drivers at both the firm and the overarching ecosystem level. These value drivers are assumed to be closely linked, changeable over time and influence whether an actor stays in the ecosystem (van der Borgh et al., 2012). They furthermore suggest that the alignment of firms' roles within the ecosystem (in terms of resources, knowledge and complementarities) and firm-level BMs with a network-oriented BM may lead the ecosystem to prevail over its disintegration. Furthermore, Ziouvelou and McGroarty (2018) suggest a next step "crowd-driven ecosystem-centric BM" that is characterized by structures powered by technology, user participation in value creation and open innovation of services. This model, however, brings new interdependence challenges that stem from further enlarging the network boundary to include the crowd as well. The inclusion of end-users as actors has been noted in other analyzed publications, too (Ehret et al., 2013; Komulainen et al., 2006).

Drawing on the evolutionary approach, Storbacka et al. (2012) argue for the interplay between the firm-level and the meso-level, where actors interact by means of practices and value is co-created through business relationships. They use the concept of a BM as a way to create an inter-actor configurational fit between the firms' BMs and network level practices, allowing for a shift of value creation outside organizational boundaries. Similar to Jabłoński (2015), who goes beyond dyadic long-term business relationships in the business ecosystem, they do not consider individual business links but strive for the orchestration of actors within the entire network setting.

Finally, the network-oriented view of a BM primarily considers network configuration, understanding how it can support the delivery of planned value proposition and what implications it has on actors' roles within the network (Andersson et al., 2014; Ehret et al., 2013). It can be used to define contracts for orchestration that can furthermore be used to manage inter-firm business relationships (Ehret et al., 2013). In a less rigid interpretation, the network-oriented view of a BM can also be used for structuring activities around role archetypes (Ikävalko et al., 2018) and thus lay the foundation for the design of actors' roles in the network (Laya et al., 2018).

\subsection{Value dimensions and value flow}

Within the networks, different value drivers are comprised of individual and shared motivations of actors. That is, on the one hand, there are individual firm ambitions for being a part of the network and the firm's expected value to be captured, and on the other, there are shared objectives that are oriented toward creating the proposed joint value (Westerlund et al., 2014). With this in mind, the proposition of Westerlund et al. (2014) is that the concept of a BM at a network level should be framed in terms of value design, i.e. an overall value architecture that explains how value is created, delivered and appropriated by the ecosystem (Suherman and Simatupang, 2017). We refer to these three notions of value (i.e. value creation, value delivery and value appropriation) in addition to value proposition as the four value dimensions that describe a BM.

Overall, value creation, or rather value co-creation, is used as the central notion of value in a network context (Markendahl et al., 2017). A general discussion of a value creation process outside firm boundaries revolves around the thinking that because of the interdependence of actors' activities toward creating one joint proposed value, that value is co-created by a network of collaborating actors (Harmon and Castro-Leon, 2018; Ikävalko et al., 2018; Storbacka et al., 2012). A similar approach is applied to value appropriation; it has to be arranged according to the roles and orchestration of actors within the value network (Iivari et al., 2016). This is why actors, their resources and performed activities need to be considered as part of the network-oriented view of a BM, and why Iivari et al. (2016) see value dimensions and value flow spanning firm boundaries.

Value co-creation needs to be coordinated (Ghanbari et al., 2017), and assigning co-creation activities is seen as part of the BM concept (Gordijn et al., 2000). The entire value flow, i.e. the value exchange that happens between the actors, needs to be considered; and the choice of adequate mechanisms of exchange is believed to rest within the concept of a BM (Storbacka et al., 2012). For example, Bankvall et al. (2017) use the network-oriented view of BM to map the contribution of each firm to the provided offering of the network and design value flow. Similarly, Suherman and Simatupang (2017) use the BM to map the value flow, and Dellyana et al. (2018) to maintain different types of BMs in line with the overarching plan (based on negotiated value exchange with other actors). Interestingly, these flows are discussed in general, but in one case, it was closely related to economic value exchange (Gordijn et al., 2000).

To sum up, for a joint offering there needs to be a joint value creation and subsequent delivery of the offer, and an adequate distribution of the appropriated value within a network. For these reasons, embodied in four value dimensions (i.e. value proposition, value creation, value delivery and value appropriation), the flow of value within the network represents an important aspect that is argued to be part of the BM concept. It can be viewed at a single-firm level where each collaborating actor has its expectations and plans, at a dyadic level where the established value flow constitutes the business relationship, and finally at a network level where overarching coordination is either described or mapped by the BM framework. These levels correspond to three viewpoints of the BM concept: a single-firm view, a dyadic-level view and a network-oriented view.

\section{Conclusions and future investigation guidelines}

The BM concept has been defined and used in a range of contexts (Massa et al., 2017) but has only recently attracted increasing attention from industrial marketing scholars. In this article, we have provided a literature review on the emerging topic of BMs in a networked business environment. As we show, authors have resorted to different literature streams on actors' interconnectedness and used different methodological approaches to argue for a network-oriented view of a BM. Some have used new terminology to refer to such a view (e.g. ecosystem $\mathrm{BM}$ ), and some have incorporated the network element within existing BM definitions. Through a discussion on different conceptualizations of a BM in a networked context and by using four central questions to describe a network- 
oriented view of a BM (Figure 5), we render the literature to four dimensions to provide an understanding of how researchers refer to the concept of a BM, in turn providing an answer to the first research question. Furthermore, acknowledging that our findings are based on the literature review of both conceptual and empirical publications that are set in an ICT context, we have no reason to believe that the presented reference to the BM concept at a network level is only applicable to an ICT setting. Therefore, we do not exclude the possibility that these conclusions and propositions are applicable in more general terms.

This review highlights the need expressed by authors of reviewed publications for a shift in BM thinking from a firmlevel to a network-level. We believe that the BM concept may be seen as a multi-level device that would allow different scales to be adopted for analysis, i.e. would allow managers to observe a value architecture from three different viewpoints. These viewpoints correspond to three levels of analysis inspired by Håkansson and Snehota (1993). The first, a single-firm view, has been the dominant one over the years. It allows the focus on a single-firm and value architecture that is specific to that firm. The second, a dyadic-level view, is where a BM could explain particularities of business relationships that a firm is a part of; therefore, acting as a linking agent between two actors. Finally, there is a network-oriented view, which we believe can be referred to as a relational aggregator, because the very nature of the BM concept at the network level is to explain value architecture represented through business relationship elements between several actors. Similarly, Klimanov and Tretyak (2019) have also recently proposed a network-based approach to BM analysis focused on managing business relationships.

Nevertheless, even if there are different BM points of view, our analysis of the underlying assumptions in the reviewed literature showed that BM designs seen from these different viewpoints coexist and coevolve over time. To some authors, firm-level BMs of the companies that collaborate on the same service development may be in conflict (for example in terms of expected incentives) but could reach a consolidated state through actors' interaction, joint discussions and joint creation of a BM at a network level. For others, the interplay of the firmand network-level BMs would allow an alignment of actors' roles and therefore strengthen both the design of firm-level BM and the BM set around the joint value proposition.

In addition, further analysis of the authors' underlying assumptions when discussing BMs at a network level indicated that they have varying standpoints with regard to which actors constitute a network and how are they interconnected. Overall, for authors that subscribe to the ecosystemic approach, the

Figure 5 Describing a network-oriented view of a BM

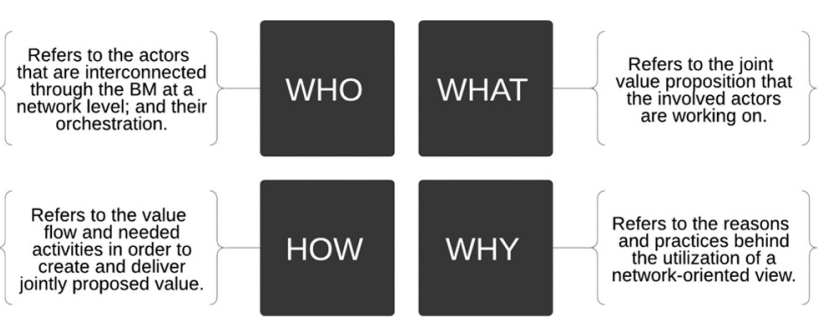

business ecosystem includes customers and partners, but also competitors and other ecosystem stakeholders. However, there are also those that think of the business ecosystem only as a multilateral set of partners, those that engage in joint utilization of complementary capabilities. Furthermore, the ecosystemic approach brings a shift to established thinking about how value is created and captured in a networked world, so it is often entangled in its assumptions with the value network literature stream. Alternatively, some authors refer to business networks and therefore only include business actors in the discussions, but also sometimes combine their reasoning with that one of a value network view.

In conclusion, we believe that the network-oriented view of BMs represents a crucial viewpoint in the networked world; one that does not require a new theoretical concept, but rather can be seen as a meso-level value architecture that describes the value flow and dynamics of value creation, delivery and capture mechanisms at a network level. These value dimensions together follow the development of new joint value propositions and coexist at the three mentioned levels. In this paper, the particularities that pertain to such a (network) view of a $\mathrm{BM}$ have been discussed, in turn answering the second research question and leading to the suggested future guidelines.

\subsection{A future research agenda}

Although the research (both conceptual and empirical) has advanced over the years and is gaining momentum, there are still open points that would further direct and focus future research efforts. We have identified several underdeveloped topics through this literature review, and here we present research guidelines for future studies that could address these shortcomings. A summary is presented in Figure 6.

The network-oriented view of a BM is introduced as a way to address complexities that arise in developing new services. Primarily, this refers to the fact that there are now more actors involved in the development and delivery of these services, especially of those based on digital technologies. Therefore, many actors need to be considered - but which? As we have

Figure 6 Avenues for a future agenda
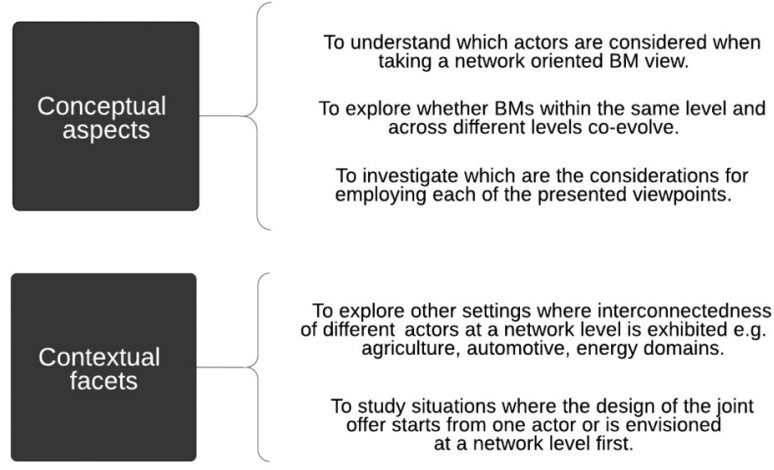

To explore other settings where interconnectedness agriculture, automotive, energy domains. To study situations where the design of the joint
offer starts from one actor or is envisioned at a network level first.

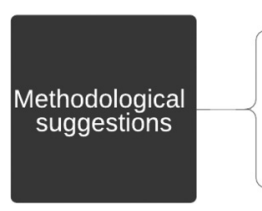

To employ research inquiries that are more engaging e.g. action research.

To develop investigations that would study the phenomenon at multiple levels simultaneously. 
seen, authors have focused on dyadic relationships and different network constellations, and in doing so have had different underlying assumptions behind the interconnectedness aspect that is apparent at a network level. Some have even analyzed ecosystems that they refer to as industry multi-sided platforms and some have considered consumers as co-creators of value. Therefore, to advance the conceptualization of the network-oriented view of a BM, a better understanding of which actors constitute the network is needed. Specifically, how can the borders of the network of actors be delineated when discussing BMs at a network level? And, can value dimensions help to inform this understanding?

Furthermore, our analysis of assumptions behind research in this field shows that there is a need to pursue further research on the co-evolution of BM designs. Building on the assumptions of several authors that firm-level and networklevel BMs develop in an interplay, it would also be beneficial to understand whether firm-level BMs of different business actors are also coevolving. In fact, very little action research has been done on a more in-depth analysis of such scenarios. As a result, we see potential in deepening our understanding of the BM concept by using methodologies that go beyond empirical examples and case studies used so far and allow the researcher to be more engaged with the phenomenon. In addition, we propose examining whether starting from the design of a firmlevel or network-level $\mathrm{BM}$ is a more adequate way to address service development in a network context.

The third investigation guideline refers to our proposition of seeing the BM as a multi-level device. In this article, the body of literature that refers to the network-oriented view of a BM was analyzed, but the importance of other viewpoints was not taken for granted. In fact, we would like to see more research at each of these levels of analysis, as well as those executed at more than one level in parallel. However, the researchers need to be more transparent and carefully choose and reflect on the viewpoint of the BM concept they use. We believe that fostering multiple levels as separate ways to see the design and implementation of BMs would contribute to the progress of BM research. To that end, we suggest further research on the following questions: What are the strong points for using each of the BM viewpoints (single-firm, dyadic-level and network-oriented views) in isolation versus jointly? Is there a unique set of dimensions that can describe a BM at each of the levels of the analysis, or is it the same set but with different aspects becoming more important depending on which level is analyzed?

Finally, on examining the empirical studies in the "final database," what emerges as the dominant empirical context is that of the IoT (Appendix). Two additional conceptual studies also discussed the concept of a BM in IoT ecosystems. However, we see further potential in many other industries where the network-oriented view of BM would be useful. For example, we came across some publications from the domains of agriculture, the automotive industry and energy (while reading papers during Step 3 of our selection process) that have explored different BM elements at a network level. Contrasting our findings concerning the network-oriented view of BMs with those from different domains would eventually strengthen the $\mathrm{BM}$ concept and allow the consolidation of extensive research efforts.

\subsection{Managerial implications}

This article provides managers with a couple of interesting implications. Firstly, based on the reviewed literature on BMs in a network context, we see a growing interest in a systematic perspective on how companies do business and think about their BMs within the value networks. This raises an important point regarding the previously dominant thinking about BMs as attributes of firms or as logics behind firms' profit formulae. Therefore, we believe that reflective managers could benefit from a shift in a mindset from an established single-firm view to a more network-oriented one. Furthermore, we find that a network-oriented view of a BM brings additional considerations regarding joint value proposition and different actors' roles and value flows in the network, which is not seen from a single-firm viewpoint. Secondly, apart from the mentioned single-firm and network-oriented viewpoints, the findings suggest a third, dyadic-level view. This suggests that in the development of services based on ICT, managers may choose to observe the BM value architecture pertaining to the firm itself, the dyadic relationship that they establish with another actor within the network or the entire value design of the network. These three viewpoints, therefore, warrant an idea of a BM as a multi-level device, which one may then use to zoom in or out of a particular level of analysis. Our intention is not to imply that one viewpoint is better than the other but rather that each of them highlights different aspects that ought to be understood. That said, managers must ensure that all aspects are covered in their efforts to steer the business in a direction that would ensure its survival in the ecosystem. Finally, bearing in mind that the reviewed papers were set in contexts where more than one actor is actively involved and participates in the development and delivery of a service based on ICT, our findings may be of particular interest to managers is such domains.

\subsection{Research limitations}

We believe this article has contributed to advancing our understanding of a BM concept at a network level by presenting state-of-the-art literature and discussions thereon. However, the article is subject to some limitations. First, our sourcing includes search data from the electronic databases of Web of Science and SciVerse Scopus. Thus, some publications might have remained unnoticed. However, we used a process of snowballing to locate further articles and thus mitigate this limitation. Second, the empirical focus of our paper is limited to networks formed around provisioning services based on ICT. We acknowledge that there are other organizational environments that do not pertain to the digital domain but still exhibit different levels of interconnectedness among actors. Thus, caution must be used when generalizing our findings to other network contexts. Third, we considered search phrases that referred to terms used to denote the BM concept at a network level, thus not including phrases that referred to BM dimensions. An example of such omitted dimensions may be the provision of value or joint value delivery. Such search keywords may be used in future research to further our understanding of particular BM dimensions and their role at each of the levels of analysis we presented in this work. In addition, the three literature streams covered in Section 2 are not exhaustive when it comes to different lines of thinking 
about the network level organizational interactions, but they are the dominant ones. Therefore, a future discussion may focus on interconnected BMs within a different stream, e.g. service-dominant logic. Finally, we are aware of the possibility of confirmation bias by which we may tend to promote information that confirms our thinking (Nickerson, 1998). To minimize this, we used a systematic literature review with a transparent multi-step process. In addition, we made sure that all publications obtained through a snowballing process also had to satisfy all the stated inclusion criteria to be included in the "final database." This process can thus serve as a starting point for future research that would expand certain criteria we used and extend our findings.

\section{References}

Adams, R.J., Smart, P. and Huff, A.S. (2017), "Shades of grey: guidelines for working with the grey literature in systematic reviews for management and organizational studies", International fournal of Management Reviews, Vol. 19 No. 4, pp. 432-454.

Alee, V. (2003), The Future of Knowledge: Increasing Prosperity through Value Networks, Butterworth-Heinemann.

Alee, V. (2009), "Value-creating networks: organizational issues and challenges", The Learning Organization, Vol. 16 No. 6, pp. 427-442.

Amit, R. and Zott, C. (2001), "Value creation in e-business", Strategic Management Fournal, Vol. 22 Nos 6/7, pp. 493-520.

Andersson, P., Markendahl, J. and Mattsson, L. (2014), "Service innovations enabled by internet of things", 30th Annual IMP Conference.

Bankvall, L., Dubois, A. and Lind, F. (2017), "Conceptualizing business models in industrial networks", Industrial Marketing Management, Vol. 60, pp. 196-203.

Basole, R.C. (2009), "Visualization of interfirm relations in a converging mobile ecosystem", fournal of Information Technology, Vol. 24 No. 2, pp. 144-159.

Bouwman, H. De Vos, H. and Haaker, T. (2008), "Mobile service innovation and business models", doi: 10.1007/9783-540-79238-3.

Bygstad, B. and Lanestedt, G. (2009), "ICT based service innovation - a challenge for project management", International fournal of Project Management, Vol. 27 No. 3, pp. 234-242.

Casadesus-Masanell, R. and Ricart, J.E. (2010), "From strategy to business models and onto tactics", Long Range Planning, Vol. 43 Nos 2/3, pp. 195-215.

Cavallo, A., Ghezzi, A. and Balocco, R. (2018), "Entrepreneurial ecosystem research: present debates and future directions", International Entrepreneurship and Management fournal, pp. 1-31.

Chesbrough, H.W. (2006), "Open business models: how to thrive in the new innovation landscape", Researchtechnology Management, Vol. 50, pp. 256.

Christensen, C.M. (1997), The Innovator's Dilemma: When New Technologies Cause Great Firms to Fail, Harvard Business Review Press, Boston, MA.

de Reuver, M., Sørensen, C. and Basole, R.C. (2018), "The digital platform: a research agenda", fournal of Information Technology, Vol. 33 No. 2, pp. 124-135.
Dellyana, D., Simatupang, T.M. and Dhewanto, W. (2018), "Managing the actor's network, business model and business model innovation to increase value of the multidimensional value networks", International fournal of Business $\mathcal{E}$ Society, Vol. 19 No. 1, pp. 209-218.

Doganova, L. and Eyquem-Renault, M. (2009), "What do business models do? Innovation devices in technology entrepreneurship", Research Policy, Vol. 38 No. 10, pp. 1559-1570.

Ehret, M., Kashyap, V. and Wirtz, J. (2013), "Business models: impact on business markets and opportunities for marketing research", Industrial Marketing Management, Vol. 42 No. 5, pp. 649-655.

Foss, N.J. and Saebi, T. (2017), "Fifteen years of research on business model innovation: how far have we come, and where should we go?", fournal of Management, Vol. 43 No. 1, pp. 200-227.

Frankenberger, K., Weiblen, T. and Gassmann, O. (2013), "Network configuration, customer centricity, and performance of open business models: a solution provider perspective", Industrial Marketing Management, Vol. 42 No. 5, pp. 671-682.

Ghanbari, A., Laya, A., Alonso-Zarate, J. and Markendahl, J. (2017), "Business development in the internet of things: a matter of vertical cooperation", IEEE Communications Magazine, Vol. 55 No. 2, pp. 135-141.

Ghezzi, A. (2013), "Revisiting business strategy under discontinuity", Management Decision, Vol. 51 No. 7, pp. 1326-1358.

Ghezzi, A., Gabelloni, D., Martini, A. and Natalicchio, A. (2018), "Crowdsourcing: a review and suggestions for future research", International fournal of Management Reviews, Vol. 20 No. 2, pp. 343-363.

Gordijn, J., Akkermans, H. and Van Vliet, H. (2000), "What's in an electronic business model?", Knowledge Engineering and Knowledge Management: Methods, Models, and Tools, pp. 257-273.

Håkansson, H. and Snehota, I. (1995), Developing Relationships in Business Networks, Routledge, London.

Håkansson, H. and Snehota, I. (2006), "No business is an island: the network concept of business strategy", Scandinavian fournal of Management, Vol. 22 No. 3, pp. 256-270.

Håkansson, H. and Snehota, I. (1993), “The content and functions of business relationships", 9th IMP Conference.

Harmon, R.R. and Castro-Leon, E.G. (2018), "Service innovation in the cloud: implications for strategy development", Technology Management for Interconnected World Service, Portland International Conference on Management of Engineering and Technology (PICMET), pp. 1-15.

Hart, C. (1998), Doing a Literature Review: Releasing the Social Science Research Imagination, SAGE Publications, London.

Heikkilä, M. and Heikkilä, J. (2010), "Conscripting of network business models”, The IUP fournal of Business Strategy, Vol. 7 No. 4, pp. 7-23.

Hynes, N. and Elwell, A.D. (2016), "The role of interorganizational networks in enabling or delaying disruptive innovation: a case study of mVoIP”, fournal of Business $\mathcal{E}$ Industrial Marketing, Vol. 31 No. 6, pp. 722-731. 
Iansiti, M. and Levien, R. (2004), "Strategy as ecology", Harvard Business Review, Vol. 82 No. 3, pp. 68-78.

Iivari, M.M., Ahokangas, P., Komi, M., Tihinen, M. and Valtanen, K. (2016), "Toward ecosystemic business models in the context of industrial internet", Fournal of Business Models, Vol. 4 No. 2, pp. 42-59.

Ikävalko, H., Turkama, P. and Smedlund, A. (2018), "Value creation in the internet of things: mapping business models and ecosystem roles", Technology Innovation Management Review, Vol. 8 No. 3, pp. 5-15.

Jabłoński, A. (2015), "The economization of network business models", Management of Network Organizations, pp. 169-180.

Jekov, B., Shoikova, E., Donchev, D. and Petkova, P. (2017), "Study on the IoT ecosystem business models and the segment of startups", 10th Annual International Conference of Education, Research and Innovation, doi: 10.21125/ iceri.2017.1291.

Karakaya, E. and Nuur, C. (2018), "Social sciences and the mining sector: some insights into recent research trends", Resources Policy, Vol. 58, pp. 257-267.

Kindström, D. and Kowalkowski, C. (2014), "Service innovation in product-centric firms: a multidimensional business model perspective", Fournal of Business \& Industrial Marketing, Vol. 29 No. 2, pp. 96-111.

Klang, D., Wallnöfer, M. and Hacklin, F. (2014), "The business model paradox: a systematic review and exploration of antecedents", International fournal of Management Reviews, Vol. 16 No. 4, pp. 454-478.

Kleindorfer, P. and Wind, Y. (2009), The Network Challenge: Strategy, Profit, and Risk in an Interlinked World, Pearson Education.

Klimanov, D. and Tretyak, O. (2019), "Linking business model research and marketing: new network-based approach to business model analysis", fournal of Business $\mathcal{E}$ Industrial Marketing, Vol. 34 No. 1, pp. 117-136.

Komulainen, H., Tuija, M., Sinisalo, J., Tahtinen, J. and Ulkuniemi, P. (2006), "Business model scenarios in mobile advertising", International fournal of Internet Marketing and Advertising, Vol. 3 No. 3, pp. 254-270.

Laya, A., Markendahl, J. and Lundberg, S. (2018), "Networkcentric business models for health, social care and wellbeing solutions in the internet of things", Scandinavian fournal of Management, Vol. 34 No. 2, pp. 103-116.

Laya, A., Jocevski, M., Ghezzi, A. and Markendahl, J. (2016), "Business model as relational aggregator: exploring business relationships", 32nd IMP Conference, Poznan, available at: www.impgroup.org/paper_view.php?viewPaper $=8894$

Leminen, S., Rajahonka, M. and Westerlund, M. (2015), "Ecosystem business models for the internet of things", Technology Innovation Management Review, Vol. 1, pp. 10-13.

Leminen, S., Rajahonka, M., Westerlund, M. and Wendelin, R. (2018), "The future of the internet of things: toward heterarchical ecosystems and service business models", fournal of Business \& Industrial Marketing, Vol. 33 No. 6, pp. 749-767.

Markendahl, J. Lundberg, S. and Kordas, O. (2017), "On the role and potential of IoT in different industries", Internet of Things Business Models, Users, and Networks.
Massa, L., Tucci, C.L. and Afuah, A. (2017), "A critical assessment of business model research", Academy of Management Annals, Vol. 11 No. 1, pp. 73-104.

Miles, M.B. and Huberman, A.M. (1994), Qualitative Data Analysis: An Expanded Sourcebook, 2d ed., SAGE Publications, Thousand Oaks, CA.

Miterev, M., Turner, J.R. and Mancini, M. (2017), "The organization design perspective on the project-based organization: a structured review", International fournal of Managing Projects in Business, Vol. 10 No. 3, pp. 527-549.

Moore, J. (1996), The Death of Competition: Leadership and Strategy in the Age of Business Ecosystems, John Wiley and Sons.

Moore, J.F. (2006), "Business ecosystems and the view from the firm", The Antitrust Bulletin, doi: 10.1177/ $0003603 \times 0605100103$.

Nambisan, S. (2018), “Architecture vs. ecosystem perspectives: reflections on digital innovation", Information and Organization, Vol. 28 No. 2, pp. 104-106.

Nelson, R.R. and Winter, S.G. (1982), An Evolutionary Theory of Economic Change, Belknap Cambridge MA, Vol. 93, $10.2307 / 2232409$.

Nenonen, S. and Storbacka, K. (2010), "Business model design: conceptualizing networked value co-creation", International Fournal of Quality and Service Sciences, Vol. 2 No. 1, pp. 43-59.

Nickerson, R.S. (1998), "Confirmation bias: a ubiquitous phenomenon in many guises", Review of General Psychology, Vol. 2 No. 2, doi: 10.1037/1089-2680.2.2.175.

Normann, R. and Ramírez, R. (1993), "From value chain to value constellation: designing interactive strategy", Harvard Business Review, Vol. 71 No. 4, pp. 65-77.

Oliveira, M.G.D., Mendes, G.H.S., Albuquerque, A.A.D. and Rozenfeld, H. (2018), "Lessons learned from a successful industrial product service system business model: emphasis on financial aspects", fournal of Business and Industrial Marketing, Vol. 33 No. 3, pp. 365-376.

Osterwalder, A. and Pigneur, Y. (2010), "Business model generation", A Handbook for Visionaries, Game Changers, and Challengers, John Wiley and Sons, Hoboken, NJ.

Palo, T. and Tähtinen, J. (2011), “A network perspective on business models for emerging technology-based services, edited by ulkuniemi", fournal of Business $\mathcal{E}$ Industrial Marketing, Vol. 26 No. 5, pp. 377-388. P.

Palo, T. and Tähtinen, J. (2013), "Networked business model development for emerging technology-based services", Industrial Marketing Management, Vol. 42 No. 5, pp. 773-782.

Podsakoff, P.M., Mackenzie, S.B., Bachrach, D.G. and Podsakoff, N.P. (2005), "The influence of management journals in the 1980s and 1990s", Strategic Management fournal, Vol. 26 No. 5, doi: 10.1002/smj. 454.

Porter, M.E. (1985), Competitive Advantage: Creating and Sustaining Superior Performance, New York, NY, doi: 10.1182/blood-2005-11-4354.

Porter, M.J. and Heppelmann, J.E. (2014), "How smart, connected products are transforming competition", Harvard Business Review, No. November.

Ramirez, R. and Mannervik, U. (2016), Strategy for a Networked World, Imperial College Press. 
Saebi, T. and Foss, N.J. (2015), "Business models for open innovation: matching heterogeneous open innovation strategies with business model dimensions", European Management Fournal, Vol. 33 No. 3, pp. 201-213.

Santos, J.B. and D'Antone, S. (2014), "Reinventing the wheel? A critical view of demand-chain management", Industrial Marketing Management, Vol. 43 No. 6, pp. 1012-1025.

Spieth, P., Schneckenberg, D. and Ricart, J.E. (2014), "Business model innovation - state of the art and future challenges for the field, $\mathrm{R}$ and", R\&D Management, Vol. 44 No. 3, pp. 237-247.

Stabell, C.B. and Fjeldstad, Ø.D. (1998), "Configuring value for competitive advantage: on chains, shops, and networks", Strategic Management fournal, Vol. 19 No. 5, pp. 413-437.

Storbacka, K. Frow, P. Nenonen, S. and Payne, A. (2012), "Designing business models for value co-creation", Special Issue - Toward a Better Understanding of the Role of Value in Markets and Marketing, pp. 51-78.

Storbacka, K., Windahl, C., Nenonen, S. and Salonen, A. (2013), "Solution business models: transformation along four continua", Industrial Marketing Management, Vol. 42 No. 5, pp. 705-716.

Stott, R.N., Stone, M. and Fae, J. (2016), "Business models in the business-to-business and business-to-consumer worlds - what can each world learn from the other?", Fournal of Business $\mathcal{E}$ Industrial Marketing, Vol. 31 No. 8, pp. 943-954.

Suherman, A.G. and Simatupang, T.M. (2017), "The network business model of cloud computing for end-to-end supply chain visibility", International Fournal of Value Chain Management, Vol. 8 No. 1, pp. 22-39.

Teece, D.J. (2010), "Business models, business strategy and innovation", Long Range Planning, Vol. 43 Nos 2/3, pp. 172-194.

Timmers, P. (1998), "Business models for electronic markets", Electronic Markets, Vol. 8 No. 2, pp. 3-8.

Tranfield, D., Denyer, D. and Smart, P. (2003), "Towards a methodology for developing evidence-informed management knowledge by means of systematic review", British fournal of Management, Vol. 14 No. 3, pp. 207-222.

Turber, S. Brocke, J. Gassmann, O. and Fleisch, E. (2014), "Designing business models in the era of internet of things: towards a reference framework", Advancing the Impact of Design Science: Moving from Theory to Practice, pp. 17-31. van der Borgh, M., Cloodt, M. and Romme, A.G.L. (2012), "Value creation by knowledge-based ecosystems: evidence from a field study", RE्D Management, Vol. 42 No. 2, pp. 150-169.

Velu, C. (2016), "Evolutionary or revolutionary business model innovation through coopetition? The role of dominance in network markets", Industrial Marketing Management, Vol. 53, pp. 124-135.

Visnjic, I., Neely, A. and Jovanovic, M. (2018), "The path to outcome delivery: interplay of service market strategy and open business models", Technovation, Vols 72/73, pp. 46-59.

Voelpel, S.C., Leibold, M. and Tekie, E.B. (2004), "The wheel of business model reinvention: how to reshape your business model to leapfrog competitors", fournal of Change Management, Vol. 4 No. 3, pp. 259-276.

Westerlund, M., Leminen, S. and Rajahonka, M. (2014), "Designing business models for the internet of things", Technology Innovation Management Review, Vol. 4 No. 7, pp. 5-14.

Wirtz, B.W., Pistoia, A., Ullrich, S. and Göttel, V. (2016), "Business models: origin, development and future research perspectives", Long Range Planning, Vol. 49 No. 1, pp. 36-54.

Wohlin, C. (2014), "Guidelines for snowballing in systematic literature studies and a replication in software engineering", Proceedings of the 18th International Conference on Evaluation and Assessment in Software Engineering, doi: 10.1145/ 2601248.2601268.

Wu, X. and Zhang, W. (2009), "Business model innovations in China: from a value network perspective", US-China Business Cooperation in the 21st Century: Opportunities and Challenges for Enterpreneurs.

Ziouvelou, X. and McGroarty, F. (2018), “A business model framework for crowd-driven IoT ecosystems", International Fournal of Social Ecology and Sustainable Development, Vol. 9 No. 3, pp. 14-33.

Zott, C. and Amit, R. (2008), "The fit between product market strategy and business model: implications for firm performance", Strategic Management Fournal, Vol. 29 No. 1, pp. 1-26.

Zott, C. and Amit, R. (2009), "The business model as the engine of Network-Based strategies", The Network Challenge - Strategy, Profit, and Risk in an Interlinked World.

Zott, C. and Amit, R. (2010), "Business model design: an activity system perspective", Long Range Planning, Vol. 43 Nos 2/3, pp. 216-226.

Zott, C., Amit, R. and Massa, L. (2011), "The business model: recent developments and future research", Fournal of Management, Vol. 37 No. 4, pp. 1019-1042. 


\section{Appendix}

Table Al Empirical studies

\begin{tabular}{|c|c|c|c|}
\hline Reference & Study context & Actors discussed/involved in the study & Method \\
\hline $\begin{array}{l}\text { Andersson et al. } \\
\text { (2014) }\end{array}$ & IoT in the automotive industry & $\begin{array}{l}\text { Car manufacturer (Volvo Cars), technology provider } \\
\text { (Ericsson), mobile operator (AT\&T), third-party service } \\
\text { provider (Linas Matkasse) }\end{array}$ & $\begin{array}{l}\text { Empirical illustration - connected } \\
\text { vehicle case }\end{array}$ \\
\hline $\begin{array}{l}\text { Dellyana et al. } \\
\text { (2018) }\end{array}$ & $\begin{array}{l}\text { Music streaming platform, } \\
\text { fashion e-commerce, } \\
\text { a web-hosting company }\end{array}$ & Each of the network's focal firms and partners & Multiple case study design \\
\hline $\begin{array}{l}\text { Ghanbari et al. } \\
\text { (2017) }\end{array}$ & IoT for smart cities & $\begin{array}{l}\text { Advertising company, end-user, telecommunication } \\
\text { equipment vendor, transport operator }\end{array}$ & Use cases in smart city \\
\hline Gordijn et al. (2000) & E-commerce & Surfer, Internet provider, peering provider & $\begin{array}{l}\text { Empirical illustration - free } \\
\text { Internet access service }\end{array}$ \\
\hline $\begin{array}{l}\text { Harmon and Castro- } \\
\text { Leon (2018) }\end{array}$ & $\begin{array}{l}\text { Cloud services } \\
\text { (artificial intelligence, } \\
\text { flying drone, health) }\end{array}$ & $\begin{array}{l}\text { Legacy software firm, a solution provider in the loT sector, a } \\
\text { cloud platform provider }\end{array}$ & $\begin{array}{l}\text { Three empirical illustrations - the } \\
\text { process of migration from goods- } \\
\text { dominant to cloud-based services }\end{array}$ \\
\hline $\begin{array}{l}\text { Heikkilä and } \\
\text { Heikkilä (2010) }\end{array}$ & $\begin{array}{l}\text { Manufacturing machinery, } \\
\text { business information system } \\
\text { and services, and telecom } \\
\text { services }\end{array}$ & $\begin{array}{l}\text { A network of three global publicly listed companies and three } \\
\text { research and funding partners }\end{array}$ & Action research study \\
\hline $\begin{array}{l}\text { lkävalko et al. } \\
\text { (2018) }\end{array}$ & $\begin{array}{l}\text { loT open innovation } \\
\text { ecosystems in a smart city } \\
\text { context }\end{array}$ & $\begin{array}{l}\text { Different actors: ideators (end-users), intermediaries (public } \\
\text { service providers, tech companies), or designers (app } \\
\text { developers) }\end{array}$ & Multiple case study design \\
\hline Jekov et al. (2017) & IoT context & $\begin{array}{l}\text { Start-ups in loT domain based on the use of big data, } \\
\text { machine learning and artificial intelligence }\end{array}$ & $\begin{array}{l}\text { Empirical illustration of start-ups - } \\
\text { acquired and stand-alone }\end{array}$ \\
\hline $\begin{array}{l}\text { Komulainen et al. } \\
\text { (2006) }\end{array}$ & M-advertising & $\begin{array}{l}\text { Description of actors involved: app and content providers, } \\
\text { MNOs, device manufacturers etc }\end{array}$ & Scenario planning \\
\hline Laya et al. (2018) & $\begin{array}{l}\text { Connected devices in the } \\
\text { context of health, social care, } \\
\text { and wellbeing }\end{array}$ & $\begin{array}{l}\text { A focal company with different associating actors in the } \\
\text { network for each of the discussed cases }\end{array}$ & Multiple case study design \\
\hline $\begin{array}{l}\text { Leminen et al. } \\
\text { (2018) }\end{array}$ & loT context & Focal company in each of the discussed cases & $\begin{array}{l}\text { Literature review and } \\
\text { multiple case study }\end{array}$ \\
\hline $\begin{array}{l}\text { Markendahl et al. } \\
\text { (2017) }\end{array}$ & IoT context & $\begin{array}{l}\text { Partner companies, municipality representatives, employer } \\
\text { organizations etc }\end{array}$ & Multiple case study \\
\hline $\begin{array}{l}\text { Palo and Tähtinen } \\
\text { (2013) }\end{array}$ & $\begin{array}{l}\text { Ubiquitous infrastructure } \\
\text { service }\end{array}$ & $\begin{array}{l}\text { Device manufacturer, media broker, operator, non-profit } \\
\text { development }\end{array}$ & Case study \\
\hline $\begin{array}{l}\text { Palo and Tähtinen } \\
\text { (2011) }\end{array}$ & $\begin{array}{l}\text { Ubiquitous, technology-based } \\
\text { service }\end{array}$ & Suppliers, partners, competitors, customers & Scenario planning \\
\hline $\begin{array}{l}\text { Suherman and } \\
\text { Simatupang (2017) }\end{array}$ & Cloud computing & Firms using and providing the cloud & $\begin{array}{l}\text { Single case study - the adoption of } \\
\text { cloud computing }\end{array}$ \\
\hline Turber et al. (2014) & IoT context & $\begin{array}{l}\text { Focal company (Nest Labs) and its collaborators (partners, } \\
\text { end-customers, and remaining stakeholders) }\end{array}$ & $\begin{array}{l}\text { Empirical illustration - connected } \\
\text { thermostat case }\end{array}$ \\
\hline $\begin{array}{l}\text { van der Borgh et al. } \\
\text { (2012) }\end{array}$ & Knowledge-based ecosystem & $\begin{array}{l}\text { Mostly technology companies, investors, } \\
\text { research institutes etc }\end{array}$ & $\begin{array}{l}\text { Single case study - high tech } \\
\text { campus in Eindhoven }\end{array}$ \\
\hline
\end{tabular}

\section{Corresponding author}

Milan Jocevski can be contacted at: jocevski@kth.se

For instructions on how to order reprints of this article, please visit our website:

www.emeraldgrouppublishing.com/licensing/reprints.htm

Or contact us for further details: permissions@emeraldinsight.com 